\title{
Redescription of Andrya cuniculi (Blanchard, 1891) (Cestoda: Anoplocephalidae), a parasite of Oryctolagus cuniculus (Lagomorpha) in Spain
}

\author{
František Tenora $^{1}$, Božena Koubková ${ }^{2}$ and Carlos Feliu ${ }^{3}$ \\ ${ }^{1}$ Department of Zoology, Mendel University of Agriculture and Forestry, Zemědělská 1, 61300 Brno, Czech Republic; \\ ${ }^{2}$ Department of Zoology and Ecology, Masaryk University, Kotlářská 2, 61137 Brno, Czech Republic; \\ ${ }^{3}$ Department of Parasitology, University of Barcelona, Av. Diagonal s/n, E-08028 Barcelona, Spain
}

Key words: Anoplocephalidae, Andrya cuniculi, redescription, Oryctolagus cuniculus

\begin{abstract}
Andrya cuniculi (Blanchard, 1891) (Cestoda: Anoplocephalidae) is redescribed from Oryctolagus cuniculus (L.) from Spain. Large ranges of variability in body length and width, testes number and position of the cirrus sac were observed. An external seminal vesicle covered with small glandular cells is present. The pattern of development of the uterus is similar to that of Andrya rhopalocephala (Riehm, 1881). The only reliable differential characters to distinguish A. cuniculi from A. rhopalocephala are the position of the uterus in gravid segments and the position of the testes in mature segments. The uterus of A. cuniculi occupies the median field and parts of the lateral fields but is restricted to the median field in A. rhopalocephala. Testes are distributed more symmetrically lateral to the female organs in $A$. cuniculi but are mostly antiporal in $A$. rhopalocephala.
\end{abstract}

Two cestode species of the genus Andrya Railliet, 1893 were described as parasites of the Leporidae (Mammalia: Lagomorpha) in Europe, Andrya rhopalocephala (Riehm, 1881) and A. cuniculi (Blanchard, 1891). Stiles (1896) used several characters to distinguish these two species, i.e., for $A$. rhopalocephala: genital pore situated near posterior corner of segment, prostatic gland elongate, scolex $1 \mathrm{~mm}$ in diameter, relatively few testes confined to antiporal half of median field, cirrus sac $0.320-0.340 \mathrm{~mm}$ long, strobila up to 60 $80 \mathrm{~cm}$ long and $5 \mathrm{~mm}$ wide; and for $A$. cuniculi: genital pores in about middle of lateral margin, prostatic gland round, scolex about $0.5 \mathrm{~mm}$ in diameter, numerous (about 50) testes scattered through entire median field, cirrus sac $0.400-0.480 \mathrm{~mm}$ long, strobila up to $100 \mathrm{~cm}$ long and $8 \mathrm{~mm}$ wide. However, subsequent descriptions of $A$. cuniculi recorded the length of strobila as $325 \mathrm{~mm}$ (Arnold 1932), 215-320 mm (Erhardová 1958) or 100$160 \mathrm{~mm}$ (Tenora et al. 1982a), and the number of testes as c. 65 (Erhardová 1958) or 40-54 (Tenora et al. 1982a). As a further reliable differentiating character between the two species, the position of the uterus relative to the excretory canals in gravid segments was proposed (Tenora and Cutillas 1982, Tenora and Cutillas Barios 1983). Several authors questioned the validity of $A$. cuniculi (Erhardová 1958) or considered it as a junior synonym of $A$. rhopalocephala (Sugár et al. 1978, Rausch 1980). Tenora and Murai (1978) recognised the problem of the validity of $A$. cuniculi as opened because of the lack of sufficient material. Several studies contributed to the knowledge of one or several morphological characters of $A$. cuniculi (Rausch 1976, 1980, Tenora et al. 1982a, 1986). However, no entire contemporary redescription of this species was published.

The generic position of $A$. cuniculi is also controversial. During the last two decades, it has been considered either as a member of Andrya (Tenora et al. 1982a, 1984, 1986, Blasco et al. 1996, Molina et al. 1998) or as a species of Paranoplocephala Lühe, 1910 (Tenora and Cutillas 1982, Tenora and Cutillas Barios 1983).

The aim of the present study is to redescribe $A$. cuniculi on the basis of newly collected specimens from its type host in Spain and to discuss its validity and generic position.

\section{MATERIALS AND METHODS}

Six gravid specimens and several fragments of $A$. cuniculi from the small intestines of Oryctolagus cuniculus (L.), captured at Navarra, Spain, were studied. They were fixed and preserved in $70 \%$ ethanol, stained with borax carmine, dehydrated, and prepared as whole mounts in Canada balsam. Voucher specimens are deposited at University of Barcelona, Department of Parasitology, Nos. 950614-2148 ArtaponaNavarra.

For comparison two slides of A. rhopalocephala from Lepus europaeus (Pallas), Hungary, were used. Voucher specimens of this material have been deposited in the Hungarian Natural History Museum, Budapest, Nos. 4452/1, 4452/2, coll. E. Murai. 
Specimens were studied with an Olympus BX 50 light microscope equipped with differential interference contrast optics and drawing tube. All specimens are apparently of unnatural shape, all being partially contracted. Measurements are given in $\mathrm{mm}$.

\section{RESULTS}

Andrya cuniculi (Blanchard, 1891)

Figs. 1-7

Redescription. Total length 28-68, maximum width 2.75. Scolex $0.42-0.46 \times 0.47-0.68$ (Fig. 1). Suckers large, $0.21-0.25 \times 0.27-0.33$. Neck 1.78-4.12 long. All proglottides wider than long, craspedote. Immature proglottides $0.26-0.28 \times 0.58-0.94$, mature proglottides $0.27-0.34 \times 0.83-2.34$, gravid proglottides $1.35-1.52 \times$ 2.51-2.75. Some immature and gravid proglottides tend to be as long as wide.

Diameter of ventral excretory canals 0.012-0.11, dorsal excretory canals $0.009-0.011$. Ventral excretory canals with transverse anastomoses, dorsal excretory canals without transverse anastomoses. Genital pores near middle or in posterior half of lateral margin of proglottides, irregularly alternating, mainly in large series. Genital atrium small, without genital papilla. Genital ducts dorsal to poral excretory canals. Single set of reproductive organs in mature proglottides. In some immature proglottides tendency for doubling of genital pores observed (Fig. 5).

Male genital primordia appearing in about $30^{\text {th }}$ proglottis, and testes in about $50^{\text {th }}$ proglottis. Testes extending between ventral excretory canals (Fig. 2), some of them slightly overlapping these canals but not crossing them (Fig. 3). Testes almost surrounding ovary from antiporal to poral regions near ventral excretory canals on both sides. Testes 70-80 in number, of irregular shape, $0.026-0.032 \times 0.037-0.049$ in mature proglottides. External seminal vesicle 0.090-0.139 in length, 0.135-0.182 in width; its surface covered with glandular cells (Fig. 4). Cirrus sac pyriform, 0.20-0.40 $\times$ $0.07-0.16$, crossing ventral excretory canal. Internal seminal vesicle 0.07-0.09 $\times 0.11-0.18$. In some cases intensely staining cells surround ductus cirri (Figs. 3, 4). Cirrus armed, length 0.049-0.057, maximum width 0.021-0.026, minimum width 0.011-0.018.

Female gonads disposed porally. Female genital primordia appearing after $10^{\text {th }}$ proglottis. Vitellarium asymmetrical, $0.08-0.11 \times 0.18-0.20$, posterior to ovary. Ovary $0.18-0.21 \times 0.40-0.42$, asymmetrical, fan-shaped, highly lobulate (Fig. 3). Mehlis' gland globular. Seminal receptacle elongate, $0.24-0.26 \times 0.15-0.19$ in mature proglottides, $0.79-0.93 \times 0.26-0.33$ in gravid proglottides. Vagina $0.090-0.132$ in length, vaginal lumen $0.008-0.015$ in width, usually opening ventrally or postero-ventrally to male pore. Vaginal surface covered with minute glands.

Initial stages of uterine development not observed. In immature, mature and gravid proglottides, a gradual development of reticulated uterus across entire ventral aspect of proglottides. Uterus extending bilaterally, restricted to median field and slightly overlapping longitudinal osmoregulatory canals (Figs. 3, 5, 6). In gravid proglottides (Fig. 7) only reticulated uterus with eggs present, seminal receptacle and cirrus sac persisting at posterior margin. In fully gravid proglottides, reticular structure not evident but trabeculae distinct. Eggs oval, deformed, 0.041-0.044 × 0.045-0.048, with pyriform apparatus. Oncospheres round, 0.020-0.031 $\times$ 0.18-0.28, embryonic hooks 0.003-0.004.

\section{DISCUSSION}

The present material is identified as Andrya cuniculi on the basis of the disposition of the testes on both sides and anteriorly to the female gonads in mature proglottides, the position of the uterus in gravid proglottides occupying the entire median field and overlapping longitudinal osmoregulatory canals. By these characters, our cestodes are clearly different from the previous descriptions of Andrya rhopalocephala (Spasskii 1951, Tenora and Murai 1978, Tenora et al. 1982a, Genov et al. 1996) and from the comparative material studied from the collection of the Hungarian Natural History Museum. Therefore, contrary to Erhardová (1958), Sugár et al. (1978) and Rausch (1980), A. cuniculi is recognised as a valid species parasitising Oryctolagus cuniculus in Western and Central Europe (Baer 1927, Sprehn 1932, Joyeux and Baer 1936, Spasskii 1951, Gvozdev et al. 1970, Tenora and Murai 1978, present study) and also introduced into USA (Arnold 1932).

Our study shows that several important characters previously used for distinguishing $A$. cuniculi from $A$. rhopalocephala exhibit very similar ranges. Specifically these are the length and the width of the strobila, the dimensions of the cirrus sac, the diameter of the scolex and the number of testes. Therefore, their differential importance is not reliable. The same is also true of the shape of the external seminal vesicle (prostatic gland,) the position of the genital pore about the middle of the lateral margin or in the posterior corner of the proglottis (considered by Stiles 1896 as characters of differential importance) and the position of the cirrus sac relative to the excretory canals (proposed as distinguishing feature by Tenora et al. 1982b). According to our results and the previous descriptions of A. rhopalocephala (Baer 1927, Joyeux and Baer 1936, Spasskii 1951, Tenora and Murai 1978), these characters are very similar in the two species compared.

Rausch (1976) did not show glandular cells on the walls of the external seminal vesicle in his illustration of the genital ducts of $A$. cuniculi. His drawing was interpreted as a sufficient evidence that this species had no such cells (Tenora and Murai 1978, Tenora and Cutillas 1982, Tenora and Cutillas Barios 1983, Tenora et al. 1984) and used as a ground to transfer this species 

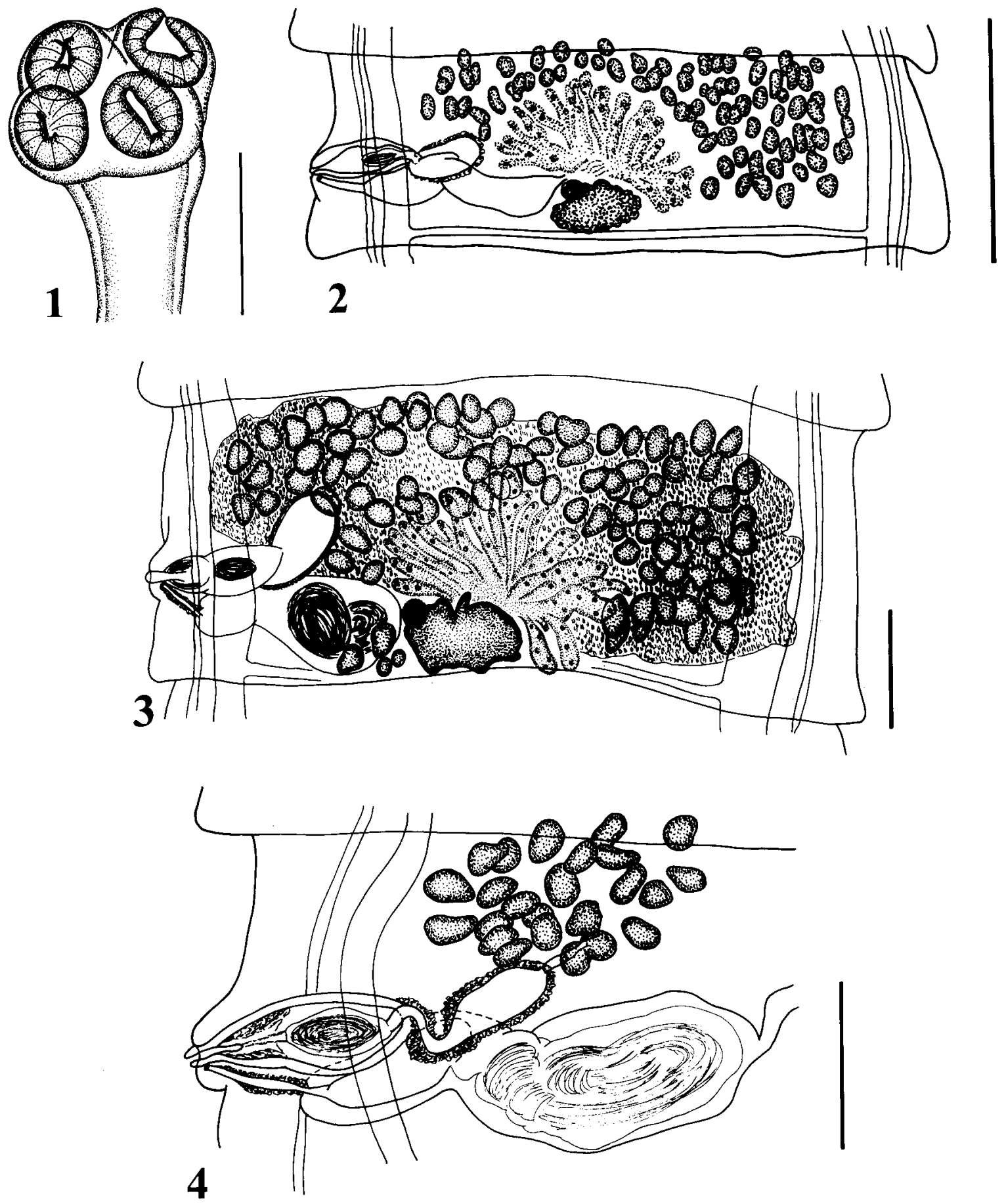

Figs. 1-4. Andrya cuniculi. Fig. 1. Scolex. Fig. 2. Immature proglottis, uterus omitted. Fig. 3. Mature proglottis. Fig. 4. Poral part of mature proglottis. Scale bars: Figs. 1, $2=0.5 \mathrm{~mm}$; Figs. 3, $4=0.2 \mathrm{~mm}$.

to the genus Paranoplocephala (Tenora and Murai 1978, Tenora et al. 1982a). The present study revealed that the external seminal vesicle of $A$. cuniculi is enclosed by intensely-stained glandular cells similar to those in the type species of Andrya (Beveridge 1994, Tenora 1998). Therefore, the position of A. cuniculi in the genus Andrya (and not in Paranoplocephala) is confirmed by this character. This generic allocation is also supported by the reticular structure of the uterus at the early developmental stages in premature and mature proglottides (see Rausch 1976, Tenora et al. 1982a, Beveridge 1994, Genov et al. 1996, Tenora 1998) for the differences in the uterine development of the two genera. 

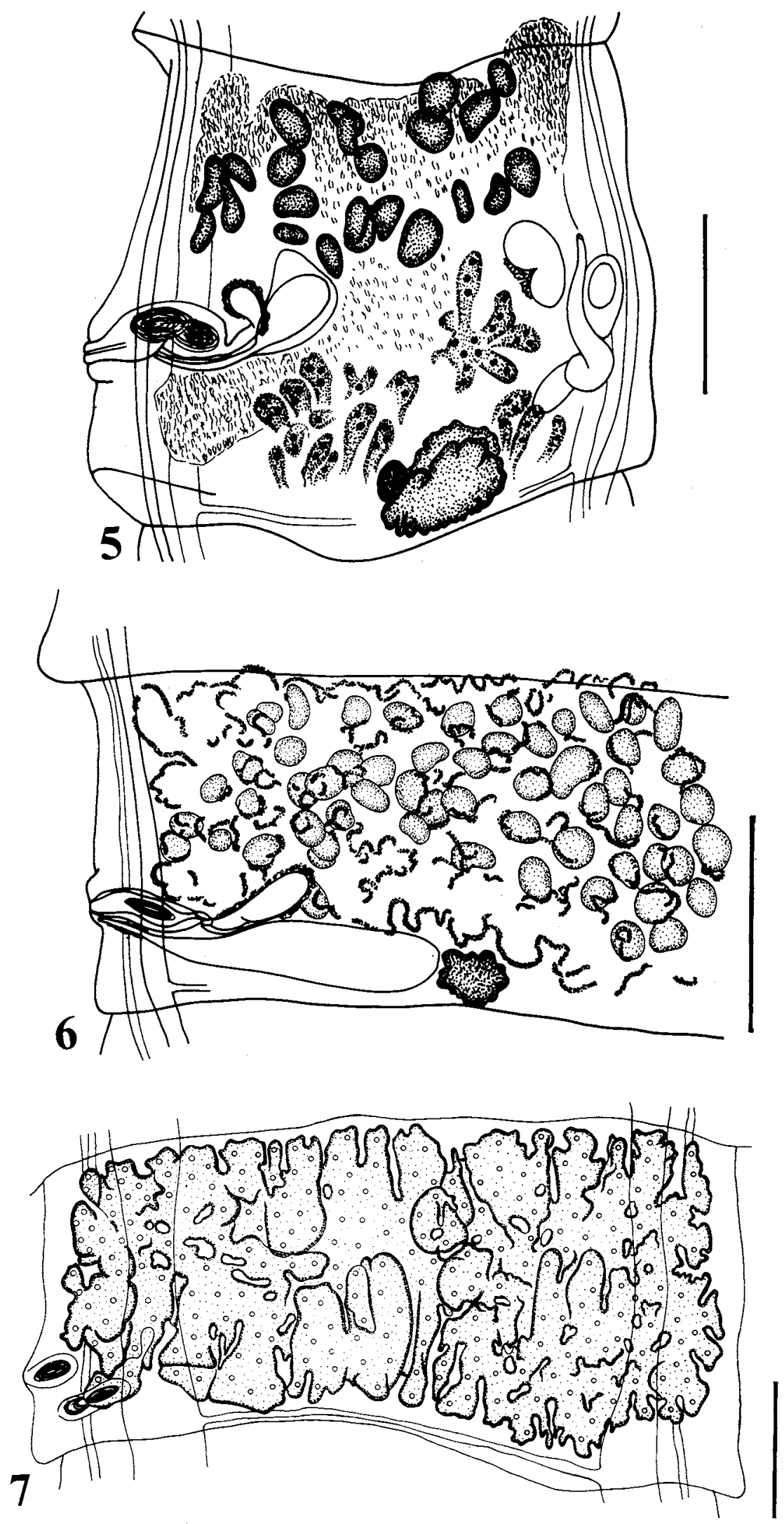

Figs. 5-7. Andrya cuniculi. Fig. 5. Immature proglottis with one poral and one antiporal opening. Fig. 6. Part of early postmature proglottis. Fig. 7. Gravid proglottis. Scale bars: Fig. $5=0.2 \mathrm{~mm}$; Figs. $6,7=0.5 \mathrm{~mm}$. 
Cestodes of the genus Andrya from the Old-World leporids resemble those of the monotypic genus Diandrya Darrah, 1930 from Nearctic marmots (for characteristics of the latter see Rausch 1980). These two genera are similar and they differ by the presence of one or two sets of genital organs per proglottis only (Rausch 1980). Rausch (1980) believed that Diandrya appeared to be a derivative of Andrya, and Beveridge (1994) placed the two genera as sister taxa forming a monophyletic clade. The present study revealed the formation of two sets of genital ducts and atria in some segments of A. cuniculi. This could be interpreted not only as a morphological abnormality (see Spasskii 1951 for a survey of similar phenomena in the Anoplocephalidae) but also as a further character supporting the possible evolutionary connection between the two groups.

Acknowledgements. The authors wish to thank Drs. É. Murai and A. Gubanyi from the Hungarian Natural History Museum in Budapest for lending specimens of $A$. rhopalocephala, and three anonymous referees for useful comments on the manuscript. The investigation was supported by the grants MSM 143100010 (Czech Republic) and PB 96-0401-CO2-1 (Spain).

\section{REFERENCES}

ARNOLD J.G. 1932: A study of the Anoplocephalinae cestodes of North American rabbits. Zoologica, Sci. Contrib. NY Zool. Soc. 23: 31-53.

BAER J.G. 1927: Monographie des cestodes de la famille Anoplocephalidae. Bull. Biol. Fr. Belg. 10: 1-241.

BEVERIDGE J. 1994: Family Anoplocephalidae Cholodkovsky, 1902. In: L.F. Khalil, A. Jones and R.A. Bray (Eds.), Keys to the Cestode Parasites of Vertebrates. CAB International, Wallingford, pp. 315-366.

BLASCO S., TORRES J., FELIU C., CASANOVA J.C., MIGUEL J., MORENO S. 1996: The helminthofauna of Oryctolagus cuniculus (Linnaeus, 1758) in Iberian Peninsula. Faunistic and ecological considerations. Parasite 4: 327-333.

ERHARDOVÁ B. 1958: Parasitische Würmer der Nagetiere in der Tschechoslowakei. Česk. Parasitol. 1: 27-103.

GENOV T., VASILEVA G.P., GEORGIEV B.B. 1996: Paranoplocephala aquatica $\mathrm{n}$. sp. (Cestoda, Anoplocephalidae) from Arvicola terrestris and Ondatra zibethica (Rodentia), with descriptions and comments on related species. Syst. Parasitol. 34: 135-152.

GVOZDEV F.V., KONTRIMAVICHUS V.L., RYZHIKOV K.M., SHALDYBIN L.S. 1970: Key to Helminths Parasitizing Leporidae. Nauka, Moskva, 232 pp. (In Russian.)

JOYEUX CH., BAER J.G. 1936: Fauna de France. 30. Cestodes. Lechevalier, édit., Paris, 613 pp.

MOLINA CH., CASANOVA J.C., FELIU C., CASTIÉN E. 1998: Studies of wild rabbit (Oryctolagus cuniculus) populations in Navarra (Spain). III. Qualitative and quantitative composition of the rabbit parasitic helminthofauna. Gibier Faune Savage, Game Wild, 15: 123-133.

RAUSCH R.L. 1976: The genera Paranoplocephala Lühe, 1910 and Anoplocephaloides Baer, 1923 (Cestoda: Anoplocephalidae), with particular reference to species in rodents. Ann. Parasitol. Hum. Comp. 51: 513-562.

RAUSCH R.L. 1980: Redescription of Diandrya composita Darrah, 1930 (Cestoda: Anoplocephalidae) from Nearctic marmots (Rodentia: Sciuridae) and the relationships of the genus Diandrya emend. Proc. Helminthol. Soc. Wash. 47: 157-164.
SPASSKII A.A. 1951: Fundamentals of Cestodology. I. Anoplocephalata. AN SSSR, Moskva, 735 pp. (In Russian.)

SPREHN E.C.W. 1932: Lehrbuch der Helminthologie. Publ. Borntraeger Brudern, Berlin, 996 pp.

STILES C.W. 1896: A revision of the adult tapeworms of hares and rabbits. Proc. U.S. Natl. Mus. 19: 145-235.

SUGÁR L., MURAI É., MÉSZAROS F. 1978: Über die Endoparasiten der wildlebenden Leporidae Ungarns. Parasitol. Hung. 11: 63-85.

TENORA F. 1998: Several comments to the systematic status of certain genera from Anoplocephalinae (Cestoda) parasites of Rodentia and Lagomorpha. Acta Univ. Agric. Silvic. Mendelianae Brunensis 1: 57-72.

TENORA F., CUTILLAS C. 1982: Systematics and taxonomy of Anoplocephalidae, parasites of hares and rabbits. Parasitol. aktuality 2: 31-35.

TENORA F., CUTILLAS BARIOS C. 1983: Notes to the systematics and taxonomy of cestodes of the suborder Anoplocephalata parasitic in mammals of the family Leporidae (Lagomorpha). Acta Univ. Agric. Brno A 1-2: 191-198.

TENORA F., MURAI É. 1978: Anoplocephalidae (Cestoda) parasites of Leporidae and Sciuridae in Europe. Acta Zool. Hung. 3-4: 415-429.

TENORA F., MURAI É., VALERO A., CUTILLAS C. 1982a: Anoplocephaloides pseudowimerosa sp. n. and other Anoplocephalidae (Cestoda) parasites of Oryctolagus cuniculus (Leporidae) in Spain. Parasitol. Hung. 14: 73-77.

TENORA F., MURAI É., VAUCHER C. 1984: On Anoplocephalidae (Cestoda), parasitizing Rodentia and Lagomorpha in Europe. Parasitol. Hung. 17: 51-57.

TENORA F., MURAI É., VAUCHER C. 1986: On Andrya Railliet, 1893 and Paranoplocephala Lühe, 1910 (Cestoda, Monieziinae). Parasitol. Hung. 19: 43-75.

TENORA F., VAUCHER C., MURAI É. 1982b: On the development of the uterus of some Anoplocephalidae (Cestoda: Paranoplocephala, Andrya). Parasitol. Hung. 14: 79-82. 